\title{
Pre-Exposure to Dennettia tripetala Ethanolic Fruit Extract Prevents Biochemical Alterations in Rats Subsequently Exposed to a Single Dose of Carbon Tetrachloride
}

\author{
Sylvia O. Iseghohi ${ }^{1, a}$, Noghayin E.J. Orhue ${ }^{1, b}$ and Kingsley Omage ${ }^{2, c}$ \\ ${ }^{1}$ Department of Biochemistry, University of Benin. P.M.B. 1154, Benin city, Edo State, Nigeria. \\ ${ }^{2}$ Department of Biochemistry, College of Basic Medical Sciences, Igbinedion University, Okada, \\ Edo State, Nigeria.
}

asylvia.iseghohi@uniben.edu, 'bnoghayin.orhue@uniben.edu, 'omagekingsey@yahoo.com

Keywords: Carbon tetrachloride, Dennettia tripetala, liver, kidney, antioxidant, steatosis.

\begin{abstract}
Dennettia tripetala (DT) is consumed in West Africa as a spice. It is also used in traditional medicine for treating cough, fever and other ailments. Its fruits have been shown to possess phytochemicals with proven antioxidant capabilities. DT roots elicit in vitro antioxidant capabilities similar to that of ascorbic acid. In this study, we evaluated the potency of the ethanol extract of DT fruits in preventing liver damage induced by a single oral administration of Carbon tetrachloride $\left(\mathrm{CCl}_{4}\right)$. Thirty female Wistar albino rats were randomized into six groups of five animals each: Group A served as control, Groups B-D were given increasing doses $(250,500$ and $1000 \mathrm{mg} / \mathrm{kg}$ b.w respectively) of DT extract for 14 days by gavage; on day 15 , they were given $\mathrm{CCl}_{4}$ $(3 \mathrm{ml} / \mathrm{kg} \mathrm{bw})$ by gavage. Group E was given the highest dose of DT for 14 days without $\mathrm{CCl}_{4}$ while Group $\mathrm{F}$ was given only $\mathrm{CCl}_{4}$ on day 15 . Administration of $\mathrm{CCl}_{4}$ resulted in liver and kidney injury detected as significant increases in plasma ALT, AST, ALP and GGT activities as well as plasma total protein, urea, creatinine, plasma and liver triglyceride and cholesterol as well as liver and kidney malondialdehyde concentrations. $\mathrm{CCl}_{4}$ also caused a reduction in liver and kidney SOD and catalase activities as well as plasma albumin concentration. Pre-treatment with Dennettia tripetala however, significantly prevented damage to the liver and kidney. Under the conditions of this study, Dennettia tripetala shows potential in preventing liver and kidney damage and has no noticeable side effects.
\end{abstract}

\section{Introduction}

Carbon tetrachloride $\left(\mathrm{CCl}_{4}\right)$ was once used as a solvent and degreaser in homes and industries until it was found to be carcinogenic and hepatotoxic [1]. The molecular mechanism of its hepatotoxicity has been well documented. It is currently used to model liver damage. $\mathrm{CCl}_{4}$ metabolism occurs primarily in the liver (and to a smaller extent in other organs that contain a high amount of cytochrome $\mathrm{P} 450$, such as the kidney). The trichloromethyl radical, which is formed from the metabolism of $\mathrm{CCl}_{4}$ by the cytochrome $\mathrm{P} 450$ enzyme, reacts rapidly with molecular oxygen to produce the trichloromethyl peroxyl radical which triggers oxidative damage to macromolecular structures in cells [1]. The trichloromethyl radical itself can also cause adduct formation and subsequent molecular damage. In the liver, molecular damage induced by $\mathrm{CCl}_{4} \mathrm{can}$ take the form of lipid peroxidation, steatosis, fibrosis, cirrhosis, hepatocellular carcinoma and liver failure in extreme cases $[1,2] . \mathrm{CCl}_{4}$ damages the kidney in a similar fashion as the liver, causing oxidative damage as well as histological alterations [3, 4].

Plants have been used for many centuries as medicine for the management of a number of diseases. This is majorly due to the presence of phytochemicals which elicit medicinal properties. Dennettia tripetala is one such plant. It grows in the rainforests of West Africa and is known in Nigeria by several names including: 'Pepperfruit', 'Ako', 'Mmimmi' and 'Ata Igbere'. Dennettia tripetala is mostly consumed for its spicy taste. It is also used in Nigeria for the treatment of cough, sore throat, toothache, diabetes, fever and nausea during pregnancy [5-7]. Its phytochemical constituents include: Saponins, tannins, flavonoids, cardiac glycosides, Dennettia essential oils, 
phenolic acids as well as alkaloids [5-8]. Dennettia tripetala contains antioxidant vitamins and has been shown to possess in vitro antioxidant activities [8-10]. The essential oil of Dennettia tripetala possesses antimicrobial and insecticidal potential [6, 11-13] as well as analgesic and antiinflammatory potential [14]. Dennettia tripetala also lowers blood glucose [15, 16].

Over the years, several studies have been conducted investigating the role of medicinal plants in experimentally induced liver and kidney damage. However, there is limited knowledge on the ability of Dennettia tripetala to prevent liver and kidney damage. In view of the phytochemical constituents of Dennettia tripetala, and the proven in vitro antioxidant activity of this plant, we carried out this study to investigate the potential of the ethanolic extract of this plant in preventing the liver and kidney of rats from undergoing free-radical damage caused by a single administration of $\mathrm{CCl}_{4}$.

\section{Material and Methods}

\section{Plant material and extract preparation}

Fresh Dennettia tripetala fruits (Figure 1) were obtained from a local market in Benin City, Nigeria. The fruits were washed with distilled water, macerated and ground into coarse powder using a milling machine. Ethanol extract of the fruit was prepared by soaking about $500 \mathrm{~g}$ of the coarse powder in $2.5 \mathrm{~L}$ of ethanol for 24 hours with regular stirring. The mixture was filtered and the extract freeze dried. A stock solution of the extract $(200 \mathrm{mg} / \mathrm{ml})$ was constituted using distilled water.

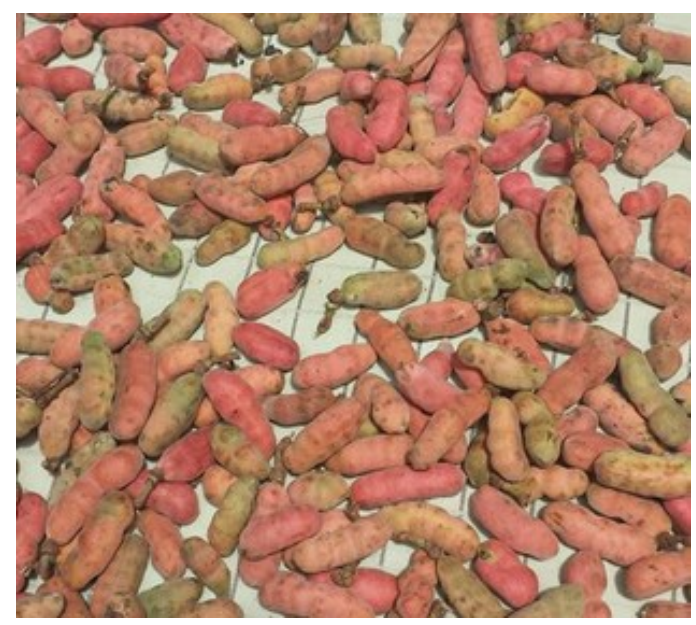

Figure 1. Mature Dennettia tripetala fruits.

\section{Carbon tetrachloride dilution}

Carbon tetrachloride solution purchased from Sigma-Aldrich (USA), was diluted with olive oil in a 1:1 (v/v) ratio. It was administered to the rats at a dose of $3 \mathrm{ml} / \mathrm{kg}$ body weight.

\section{Experimental animals and design}

Thirty (30) female Wistar albino rats weighing between 120-150g were used for this study. The animals were kept in clean disinfected iron cages, in a well ventilated room and allowed free access to water and feed. Following a two-week acclimatization period, the animals were randomized into six groups of five animals each and treated as follows:

GROUP A: Control (feed only)

GROUP B: Given $250 \mathrm{mg} / \mathrm{kg}$ body weight of extract for 14 days $+\mathrm{CCl}_{4}$ on day 15 .

GROUP C: Given $500 \mathrm{mg} / \mathrm{kg}$ body weight of extract for 14 days $+\mathrm{CCl}_{4}$ on day 15 .

GROUP D: Given $1000 \mathrm{mg} / \mathrm{kg}$ body weight of extract for 14 days $+\mathrm{CCl}_{4}$ on day 15 .

GROUP E: Given $1000 \mathrm{mg} / \mathrm{kg}$ body weight of extract for 14 days

GROUP F: Given $\mathrm{CCl}_{4}$ on day 15 .

All animals were handled in strict accordance with the NIH guide for the care and use of laboratory animals. 


\section{Administration of the extract and $\mathrm{CCl}_{4}$}

The stock solution of plant extract was administered orally at varying doses, (as stated above) for a period of fourteen days. On day fifteen, a single dose of $\mathrm{CCl}_{4}$ was also administered orally to the animals.

\section{Sample collection}

On day sixteen the animals were sacrificed by chloroform anaesthesia after an overnight fast. Blood samples were collected and the plasma obtained, was used for biochemical analyses. The liver of each rat was also collected, weighed and homogenized with normal saline $(1: 5 \mathrm{w} / \mathrm{v})$. The tissue homogenates were centrifuged at $4000 \mathrm{rpm}$ for 10 minutes and the supernatant obtained were used for biochemical analysis.

\section{Assay methods}

The following kits were purchased from Randox Laboratories (United Kingdom): Alanine aminotransferase (ALT), Aspartate transaminase (AST), Alkaline phosphatase (ALP), Gamma glutamyl transferase (GGT), urea, creatinine, total protein, albumin, cholesterol and triglyceride kits. The assays were carried out following the manufacturer's protocols. Superoxide dismutase activity was assayed for using the method of Misra and Fridovich [17]. Catalase activity was assayed for using the method of Goth [18]. Malondialdehyde concentration was assayed for using the method of Buege and Aust [19].

\section{Statistical analysis}

Data are represented as Mean \pm S.E.M $(n=5)$. Significance of Difference was tested by oneway ANOVA, followed by Tukey test. GraphPad Prism Version 6 (GraphPad Software Inc. San Diego, California USA) was used for this analysis. Statistical Significance was set at $\mathrm{P}<0.05$.

\section{Results}

Table 1 shows that $\mathrm{CCl}_{4}$ caused a significant $(\mathrm{P}<0.001)$ increase in AST, ALT, ALP and GGT activities compared to control. Pre-administration of the plant extract significantly $(\mathrm{P}<0.05)$ prevented this increase in a dose-dependent manner. The plant extract when administered alone did not alter these parameters significantly when compared to control.

Table 1. Effect of Ethanolic extract of Dennettia tripetala fruits on liver marker enzymes in plasma of rats exposed to carbon tetrachloride.

\begin{tabular}{|c|l|l|l|l|l|}
\hline Groups & Treatment & AST $(\mathbf{U} / \mathbf{L})$ & ALT $(\mathbf{U} / \mathbf{L})$ & ALP $(\mathbf{U} / \mathbf{L})$ & GGT (U/L) $\left(\mathbf{x 1 0} \mathbf{s}^{-3}\right)$ \\
\hline A & Control & $27.25 \pm 1.11^{\mathrm{a}}$ & $28.00 \pm 0.45^{\mathrm{a}}$ & $107.9 \pm 2.74^{\mathrm{a}}$ & $1158 \pm 0.01^{\mathrm{a}}$ \\
\hline B & ETDT $250+\mathrm{CCl}_{4}$ & $70.25 \pm 0.25^{\mathrm{b}}$ & $76.33 \pm 0.33^{\mathrm{b}}$ & $208.3 \pm 0.46^{\mathrm{b}}$ & $8878 \pm 386.0^{\mathrm{b}}$ \\
\hline C & ETDT $500+\mathrm{CCl}_{4}$ & $57.50 \pm 0.29^{\mathrm{c}}$ & $76.67 \pm 0.33^{\mathrm{b}}$ & $171.2 \pm 1.06^{\mathrm{c}}$ & $9264 \pm 668.6^{\mathrm{b}}$ \\
\hline D & ETDT $1000+\mathrm{CCl}_{4}$ & $40.67 \pm 0.33^{\mathrm{d}}$ & $73.67 \pm 1.33^{\mathrm{b}}$ & $153.6 \pm 1.03^{\mathrm{c}}$ & $5018 \pm 386.0^{\mathrm{a}}$ \\
\hline E & ETDT 1000 & $24.50 \pm 0.29^{\mathrm{a}}$ & $29.33 \pm 0.67^{\mathrm{a}}$ & $117.5 \pm 2.56^{\mathrm{a}}$ & $3474 \pm 0.01^{\mathrm{a}}$ \\
\hline F & $\mathrm{CCl}_{4}$ & $116.70 \pm 4.41^{\mathrm{e}}$ & $97.00 \pm 0.41^{\mathrm{c}}$ & $267.9 \pm 12.53^{\mathrm{d}}$ & $10,422 \pm 1215^{\mathrm{b}}$ \\
\hline
\end{tabular}

Values are presented as mean \pm SEM. Values with different superscripts in the same column, differ significantly from one another. Values with the same superscript in a column are not significantly different from one another. $\mathrm{n}=5$ rats per group. ETDT means ethanolic extract of Dennettia tripetala.

Table 2 shows that $\mathrm{CCl}_{4}$ caused a significant $(\mathrm{P}<0.001)$ increase in the concentrations of cholesterol and triglyceride in the liver of the rats. Pre-administration of the plant extract significantly $(\mathrm{P}<0.001)$ prevented this increase. The plant extract when administered alone did not alter these parameters significantly when compared to control. 
Table 2. Effect of ethanolic extract of Dennettia tripetala fruits on liver lipid profile of rats exposed to carbon tetrachloride.

\begin{tabular}{|c|l|c|c|}
\hline Groups & \multicolumn{1}{|c|}{ Treatment } & CHOL (mg/dl) & TAG (mg/dl) \\
\hline A & Control & $154.8 \pm 0.28^{\mathrm{a}}$ & $146.4 \pm 1.01^{\mathrm{a}}$ \\
\hline B & ETDT $250+\mathrm{CCl}_{4}$ & $159.0 \pm 0.63^{\mathrm{b}}$ & $152.3 \pm 0.66^{\mathrm{b}}$ \\
\hline $\mathrm{C}$ & ETDT $500+\mathrm{CCl}_{4}$ & $158.4 \pm 0.53^{\mathrm{b}}$ & $152.9 \pm 0.71^{\mathrm{c}}$ \\
\hline $\mathrm{D}$ & ETDT $1000+\mathrm{CCl}_{4}$ & $155.7 \pm 0.45^{\mathrm{a}}$ & $154.3 \pm 1.48^{\mathrm{c}}$ \\
\hline E & ETDT 1000 & $153.1 \pm 0.91^{\mathrm{a}}$ & $146.1 \pm 0.32^{\mathrm{a}}$ \\
\hline $\mathrm{F}$ & $\mathrm{CCl}_{4}$ & $168.8 \pm 0.29^{\mathrm{c}}$ & $254.8 \pm 2.18^{\mathrm{d}}$ \\
\hline
\end{tabular}

Values are presented as mean \pm SEM. Values with different superscripts in the same column, differ significantly from one another. Values with the same superscript in a column are not significantly different from one another. $\mathrm{n}=5$ rats per group. ETDT means ethanolic extract of Dennettia tripetala.

Table 3 shows that $\mathrm{CCl}_{4}$ caused a significant $(\mathrm{P}<0.01)$ increase in plasma cholesterol and triglyceride concentration. Pre-administration of the plant extract significantly $(\mathrm{P}<0.05)$ prevented this increase. The plant extract when administered alone did not alter these parameters significantly when compared to control.

Table 4 shows that $\mathrm{CCl}_{4}$ caused a significant $(\mathrm{P}<0.001)$ increase in plasma total protein and a significant $(\mathrm{P}<0.001)$ decrease in plasma albumin compared to control. Pre-administration of the plant extract significantly $(\mathrm{P}<0.05)$ prevented the increase in total protein and decrease in albumin. Administration of only the plant extract did not significantly alter the total protein levels but led to a reduction in plasma albumin.

Table 3. Effect of ethanolic extract of Dennettia tripetala fruits on plasma lipid profile of rats exposed to carbon tetrachloride.

\begin{tabular}{|c|l|c|c|}
\hline Groups & \multicolumn{1}{|c|}{ Treatment } & CHOL $(\mathbf{m g} / \mathbf{d l})$ & TAG $(\mathbf{m g} / \mathbf{d l})$ \\
\hline A & Control & $129.6 \pm 1.41^{\mathrm{a}}$ & $151.10 \pm 0.51^{\mathrm{a}}$ \\
\hline B & ETDT $250+\mathrm{CCl}_{4}$ & $127.8 \pm 0.95^{\mathrm{a}}$ & $159.9 \pm 3.19^{\mathrm{ab}}$ \\
\hline $\mathrm{C}$ & ETDT $500+\mathrm{CCl}_{4}$ & $128.8 \pm 0.62^{\mathrm{a}}$ & $160.8 \pm 1.37^{\mathrm{ab}}$ \\
\hline $\mathrm{D}$ & ETDT $1000+\mathrm{CCl}_{4}$ & $132.4 \pm 0.54^{\mathrm{a}}$ & $157.7 \pm 0.96^{\mathrm{ab}}$ \\
\hline E & ETDT 1000 & $125.6 \pm 1.98^{\mathrm{a}}$ & $149.9 \pm 0.98^{\mathrm{a}}$ \\
\hline $\mathrm{F}$ & $\mathrm{CCl}_{4}$ & $143.3 \pm 0.52^{\mathrm{b}}$ & $168.7 \pm 3.62^{\mathrm{b}}$ \\
\hline
\end{tabular}

Values are presented as mean \pm SEM. Values with different superscripts in the same column, differ significantly from one another. Values with the same superscript in a column are not significantly different from one another. $\mathrm{n}=5$ rats per group. ETDT means ethanolic extract of Dennettia tripetala. 
Table 4. Effect of ethanolic extract of Dennettia tripetala fruits on plasma protein profile of rats exposed to carbon tetrachloride.

\begin{tabular}{|c|c|c|c|}
\hline Groups & Treatment & Total protein (g/dl) & Albumin (g/dl) \\
\hline A & Control & $5.71 \pm 0.03^{\mathrm{a}}$ & $4.34 \pm 0.13^{\mathrm{a}}$ \\
\hline B & ETDT $250+\mathrm{CCl}_{4}$ & $6.05 \pm 0.01^{\mathrm{b}}$ & $3.54 \pm 0.09^{\mathrm{b}}$ \\
\hline $\mathrm{C}$ & ETDT $500+\mathrm{CCl}_{4}$ & $5.93 \pm 0.01^{\mathrm{c}}$ & $3.63 \pm 0.17^{\mathrm{b}}$ \\
\hline $\mathrm{D}$ & ETDT $1000+\mathrm{CCl}_{4}$ & $5.85 \pm 0.01^{\mathrm{c}}$ & $3.31 \pm 0.10^{\mathrm{bc}}$ \\
\hline E & ETDT 1000 & $5.79 \pm 0.04^{\mathrm{a}}$ & $3.53 \pm 0.07^{\mathrm{b}}$ \\
\hline $\mathrm{F}$ & $\mathrm{CCl}_{4}$ & $6.17 \pm 0.01^{\mathrm{d}}$ & $2.75 \pm 0.10^{\mathrm{c}}$ \\
\hline
\end{tabular}

Values are presented as mean \pm SEM. Values with different superscripts in the same column, differ significantly from one another. Values with the same superscript in a column are not significantly different from one another. $\mathrm{n}=5$ rats per group. ETDT means ethanolic extract of Dennettia tripetala.

Table 5 shows that in the liver of the rats, $\mathrm{CCl}_{4}$ caused a significant $(\mathrm{P}<0.05)$ decrease in superoxide dismutase (SOD) and catalase activities as well as a significant increase $(\mathrm{P}<0.05)$ in MDA levels compared to control. Pre-administration with the plant extract significantly $(\mathrm{P}<0.05)$ prevented these alterations. Administration of only the plant extract did not significantly alter the activity of SOD but led to a decrease in Catalase activity and a decrease in malondialdehyde (negligible when compared to the $\mathrm{CCl}_{4}$ only group).

Table 5. Effect of ethanolic extract of Dennettia tripetala fruits on the activity of antioxidant enzymes and lipid peroxidation status in liver of rats exposed to carbon tetrachloride.

\begin{tabular}{|c|l|c|c|c|}
\hline Groups & \multicolumn{1}{|c|}{ Treatment } & $\begin{array}{c}\text { SOD } \\
\text { (Units/g wet tissue) }\end{array}$ & $\begin{array}{c}\text { CAT } \\
\text { (Units/g wet tissue) }\end{array}$ & $\begin{array}{c}\text { MDA } \\
\text { (Units/g wet tissue) }_{\left(\mathbf{x ~ 1 0}^{\mathbf{3}} \text { ) }\right.}\end{array}$ \\
\hline $\mathrm{A}$ & Control & $377.8 \pm 9.98^{\mathrm{a}}$ & $6108 \pm 42.55^{\mathrm{a}}$ & $0.19 \pm 0.01^{\mathrm{a}}$ \\
\hline $\mathrm{B}$ & ETDT $250+\mathrm{CCl}_{4}$ & $516.7 \pm 32.10^{\mathrm{ab}}$ & $5519 \pm 78.11^{\mathrm{b}}$ & $0.23 \pm 0.01^{\mathrm{b}}$ \\
\hline $\mathrm{C}$ & ETDT $500+\mathrm{CCl}_{4}$ & $327.2 \pm 45.76^{\mathrm{ac}}$ & $5810 \pm 101.9^{\mathrm{a}}$ & $0.23 \pm 0.01^{\mathrm{b}}$ \\
\hline $\mathrm{D}$ & ETDT $1000+\mathrm{CCl}_{4}$ & $450.8 \pm 33.45^{\mathrm{abc}}$ & $5580 \pm 101.4^{\mathrm{b}}$ & $0.23 \pm 0.01^{\mathrm{b}}$ \\
\hline $\mathrm{E}$ & ETDT 1000 & $378.9 \pm 36.62^{\mathrm{a}}$ & $5530 \pm 12.00^{\mathrm{b}}$ & $0.24 \pm 0.02^{\mathrm{b}}$ \\
\hline $\mathrm{F}$ & $\mathrm{CCl}_{4}$ & $263.3 \pm 21.31^{\mathrm{ad}}$ & $4830 \pm 52.98^{\mathrm{c}}$ & $0.27 \pm 0.02^{\mathrm{c}}$ \\
\hline
\end{tabular}

Values are presented as mean \pm SEM. Values with different superscripts in the same column, differ significantly from one another. Values with the same superscript in a column are not significantly different from one another. $\mathrm{n}=5$ rats per group. ETDT means ethanolic extract of Dennettia tripetala.

Table 6 shows that $\mathrm{CCl}_{4}$ caused a significant $(\mathrm{P}<0.01)$ increase in urea and creatinine levels compared to control. The plant extract significantly $(\mathrm{P}<0.05)$ prevented this increase. Administration of only the plant extract did not significantly alter these parameters.

Table 7 shows that in the kidney of the rats, $\mathrm{CCl}_{4}$ caused a significant $(\mathrm{P}<0.05)$ decrease in SOD and catalase activities as well as a significant increase $(\mathrm{P}<0.05)$ in MDA levels compared to control. Pre-administration with the plant extract significantly $(\mathrm{P}<0.05)$ prevented these alterations. Administration of only the plant extract did not significantly alter these parameters when compared to control. 
Table 6. Effect of ethanolic extract of Dennettia tripetala fruits on urea and creatinine concentrations in plasma of rats exposed to carbon tetrachloride.

\begin{tabular}{|c|l|c|c|}
\hline Groups & \multicolumn{1}{|c|}{ Treatment } & Urea $(\mathbf{m g} / \mathbf{d l})$ & Creatinine $(\mathbf{m g} / \mathbf{d l})$ \\
\hline A & Control & $84.81 \pm 0.18^{\mathrm{a}}$ & $1.86 \pm 0.07^{\mathrm{a}}$ \\
\hline B & ETDT $250+\mathrm{CCl}_{4}$ & $90.15 \pm 0.72^{\mathrm{a}}$ & $2.00 \pm 0.03^{\mathrm{a}}$ \\
\hline $\mathrm{C}$ & ETDT $500+\mathrm{CCl}_{4}$ & $91.70 \pm 2.06^{\mathrm{a}}$ & $1.61 \pm 0.33^{\mathrm{a}}$ \\
\hline $\mathrm{D}$ & ETDT $1000+\mathrm{CCl}_{4}$ & $86.79 \pm 3.99^{\mathrm{a}}$ & $2.23 \pm 0.29^{\mathrm{a}}$ \\
\hline E & ETDT 1000 & $92.01 \pm 1.08^{\mathrm{a}}$ & $1.01 \pm 0.09^{\mathrm{b}}$ \\
\hline $\mathrm{F}$ & $\mathrm{CCl}_{4}$ & $120.20 \pm 8.06^{\mathrm{b}}$ & $3.22 \pm 0.13^{\mathrm{c}}$ \\
\hline
\end{tabular}

Values are presented as mean \pm SEM. Values with different superscripts in the same column, differ significantly from one another. Values with the same superscript in a column are not significantly different from one another. $\mathrm{n}=5$ rats per group. ETDT means ethanolic extract of Dennettia tripetala.

Table 7. Effect of ethanolic extract of Dennettia tripetala fruits on the activity of antioxidant enzymes and lipid peroxidation status in kidney of rats exposed to carbon tetrachloride.

\begin{tabular}{|c|l|c|c|c|}
\hline Groups & Treatment & $\begin{array}{c}\text { SOD } \\
\text { (Units/g wet tissue) }\end{array}$ & $\begin{array}{c}\text { CAT } \\
\text { (Units/g wet tissue) }\end{array}$ & $\begin{array}{c}\text { MDA } \\
\text { (Units/g wet tissue) (x 10 }^{\mathbf{3}} \text { ) }\end{array}$ \\
\hline A & Control & $108.0 \pm 3.34^{\mathrm{a}}$ & $4005 \pm 156.5^{\mathrm{a}}$ & $0.09 \pm 0.01^{\mathrm{a}}$ \\
\hline $\mathrm{B}$ & ETDT 250 $+\mathrm{CCl}_{4}$ & $85.58 \pm 7.65^{\mathrm{b}}$ & $3624 \pm 46.86^{\mathrm{ab}}$ & $0.10 \pm 0.01^{\mathrm{b}}$ \\
\hline $\mathrm{C}$ & ETDT $500+\mathrm{CCl}_{4}$ & $100.20 \pm 6.00^{\mathrm{a}}$ & $3744 \pm 49.57^{\mathrm{a}}$ & $0.10 \pm 0.02^{\mathrm{b}}$ \\
\hline $\mathrm{D}$ & ETDT $1000+\mathrm{CCl}_{4}$ & $77.53 \pm 3.39^{\mathrm{b}}$ & $4125 \pm 77.13^{\mathrm{ac}}$ & $0.09 \pm 0.02^{\mathrm{a}}$ \\
\hline $\mathrm{E}$ & ETDT 1000 & $85.21 \pm 6.23^{\mathrm{b}}$ & $3606 \pm 26.15^{\mathrm{ab}}$ & $0.09 \pm 0.01^{\mathrm{a}}$ \\
\hline $\mathrm{F}$ & $\mathrm{CCl}_{4}$ & $59.36 \pm 0.68^{\mathrm{c}}$ & $2016 \pm 78.63^{\mathrm{d}}$ & $0.15 \pm 0.01^{\mathrm{c}}$ \\
\hline
\end{tabular}

Values are presented as mean \pm SEM. Values with different superscripts in the same column, differ significantly from one another. Values with the same superscript in a column are not significantly different from one another. $\mathrm{n}=5$ rats per group. ETDT means ethanolic extract of Dennettia tripetala.

\section{Discussion}

The liver is an important organ in the body with multiple functions including the detoxification of xenobiotics, which predisposes it to drug-induced damage. Markers of liver damage such as ALT, AST, ALP and GGT are often used to assess liver function. The level of these enzymes in the blood is usually under tight regulation therefore an increase in the plasma level of these enzymes may indicate a breach in liver integrity [20]. In this study, the well-known hepatotoxicant, carbon tetrachloride $\left(\mathrm{CCl}_{4}\right)$ was used to test the effectiveness of the ethanolic extract of Dennettia tripetala fruits in protecting the liver of rats from molecular damage.

The results of this study showed that $\mathrm{CCl}_{4}$ caused an increase in the plasma levels of ALT, AST, ALP and GGT. The increase in the plasma level of these enzymes is most likely due to free radical damage to the membrane of the hepatocytes; as studies have shown that trichloromethyl peroxy radical (a product of $\mathrm{CCl}_{4}$ metabolism) is capable of causing oxidative damage to subcellular structures including the cell membrane [1]. In the present study, administration of Dennettia tripetala for 14 days prior to a single administration of carbon tetrachloride significantly protected the liver from this damage. This may be due to the intrinsic antioxidant content of the plant. Dennettia tripetala has been shown to possess antioxidant vitamins A and C as well as phytochemicals with proven antioxidant actions such as flavonoids [21]. Dennettia tripetala may have helped to manage or quench the free radicals generated by the metabolism of $\mathrm{CCl}_{4}$. 
Lipid homeostasis is tightly regulated in the liver. Liver injury can take the form of steatosis which is the accumulation of lipids, chiefly triglycerides in the liver [20]. $\mathrm{CCl}_{4}$ can cause steatosis by increasing the synthesis of triglycerides and cholesterol in the liver [22], and by inhibition of beta-oxidation of fatty acids and decreasing the secretion of lipids [23]. Suppression of lysosomal acid triglyceride lipase activity also leads to accumulation of triglycerides in hepatocytes of rats exposed to $\mathrm{CCl}_{4}[24,25]$. Results of the present study showed that $\mathrm{CCl}_{4}$ caused triglyceride and cholesterol to accumulate in the liver. Pre-administration of Dennettia tripetala ethanolic extract protected the liver from steatosis.

Elevation of cholesterol in the serum may be due to the inability of the liver to remove cholesterol from the blood [26]. On the other hand, elevation in serum triglyceride levels may be as a result of a reduction in the activity of peripheral lipase [27]. In the present study, $\mathrm{CCl}_{4}$ administration resulted in significant elevations in the plasma levels of triglyceride and cholesterol, indicating alterations to lipid metabolism. Dennettia tripetala ethanolic extract was able to prevent this disturbance in lipid homeostasis.

Albumin is synthesized by the liver and is the major protein found in blood. It is therefore used to determine the synthetic capacity of the liver [20]. The results from the present study showed that $\mathrm{CCl}_{4}$ caused a reduction in plasma albumin. This is probably a result of decreased synthesis of albumin, indicating damage to the liver. The plant extract was able to prevent this decrease. On the other hand, the total protein content of the plasma increased. This may be due to the enzymes which leaked out of the liver into the plasma due to the porous membranes of the hepatocytes as previously discussed.

Superoxide dismutase and Catalase are enzymes that normally function to combat free radicals and a decrease in their activity may indicate free radical damage. The present study showed that $\mathrm{CCl}_{4}$ administration caused significant decreases in the activities of SOD and Catalase in the liver. $\mathrm{CCl}_{4}$ also caused an increase in malondialdehyde levels which indicates lipid peroxidation in the liver. Dennettia tripetala ethanolic extract was able to prevent the decline in SOD and Catalase activities as well as significantly inhibit lipid peroxidation.

Carbon tetrachloride is also known to cause damage to kidneys. It is distributed at high concentrations in the kidney [28]. It has a high affinity for the cortex of the kidney due to the high content of cytochrome P450 enzymes $[4,29]$. The mechanism by which it exerts damage to the kidneys is similar to that of the liver (free radical damage from the trichloromethyl and its peroxyradicals).

Urea and creatinine are usually filtered from the blood by the kidney, therefore an increase in the levels of these metabolites in the blood shows that there is damage to the kidney. In the present study, $\mathrm{CCl}_{4}$ caused significant elevations in plasma levels of urea and creatinine. Pre-administration of the Dennettia tripetala ethanolic extract significantly prevented this increase. $\mathrm{CCl}_{4}$ also caused a reduction in SOD and catalase activities in the kidney as well as an increase in malondialdehyde levels in the kidney, indicating lipid peroxidation and oxidative stress. Dennettia tripetala ethanolic extract prevented these alterations.

\section{Conclusion}

Data from the present study show that the ethanolic extract of Dennettia tripetala fruits has the potential to protect the liver and kidneys of rats from damage when it is administered daily for two weeks prior to the administration of a single dose of $\mathrm{CCl}_{4}$. The mechanism by which this protection occurs is most likely an inhibition of free radical damage, as the data in this paper shows that the plant extract prevented the decline in antioxidant enzymes in the liver and kidney of the rats; and also prevented lipid peroxidation. Molecular experiments designed to study the details of the mechanism by which Dennettia tripetala elicits this protective activity need to be carried out. It will also be interesting to find out if Dennettia tripetala will be effective in preventing liver and kidney damage caused by multiple exposures to carbon tetrachloride. 
List of abbreviations. $\mathrm{CCl}_{4}=$ Carbon tetrachloride, ETDT $=$ Ethanolic extract of Dennettia tripetala, $\mathrm{SOD}=$ Superoxide dismutase, $\mathrm{CAT}=$ Catalase, $\mathrm{CHOL}=$ Cholesterol, $\mathrm{TAG}=$ Triacyl glycerol, $\mathrm{SEM}=$ Standard error of mean .

\section{References}

[1] L.W. Weber, M. Boll, A. Stampfl, Hepatotoxicity and mechanism of action of haloalkanes: carbon tetrachloride as a toxicological model, Crit Rev Toxicol. 33 (2003) 150-136.

[2] L.M. Berger et al., $\mathrm{CCl}_{4}$-induced toxicity in isolated hepatocytes: The importance of direct solvent injury, Hepatology. 6 (1986) 36-45.

[3] M. Al-Yahya et al., Attenuation of $\mathrm{CCl}_{4}$-induced oxidative stress and hepatonephrotoxicity by Saudi Sidr honey in rats, Evid. based compl. Alt. Med. (2013) 1-10.

[4] P. Abraham, G. Wilfred, S.P. Cathrine, Oxidative damage to the lipids and proteins of the lungs, testes and kidney of rats during carbon tetrachloride intoxication, Clinica. Chimica. Acta. 289 (1999) 177-179.

[5] S.O. Iseghohi, A review of the uses and medicinal properties of Dennettia tripetala (Pepperfruit), Med. Sci. 3 (2015) 104-111.

[6] B.O. Ejechi, D.E. Akpomedaye, Activity of essential oil and phenolic acid extracts of pepperfruit (Dennettia tripetala G. Baker; Anonaceae) against some food-borne microorganisms, Afr. J. Biotech. 4 (2005) 258-261.

[7] D.E. Okwu, F.N.I. Morah, Mineral and nutritive value of Dennettia tripetala fruits, Fruits. 59 (2004) 437-442.

[8] N.P. Okolie, A. Falodun, O. Davids, Evaluation of the antioxidant activity of the root extract of Pepperfruit (Dennettiatripetala) and its potential for the inhibition of lipid peroxidation, Afr. J. Trad. Compl. Alt. Med. 11 (2014) 221-227.

[9] U.E. Odoh, C.O. Ezugwu, J.C. Dike, The phenolic content and antioxidant effect of the methanol extract of Dennettia tripetala G. Baker (Annonaceae), Planta Med. 80(10) (2014).

[10] M.A. Aderogba, E.O. Akinkunmi, W.T. Mabusela, Antioxidant and antimicrobial activities of flavonoid glycosides from Dennettia tripetala G. Baker leaf extract, Nig. J. Nat. Pro. Med. 15 (2011) 49-52.

[11] E. Nwachukwu, J. Osuji, Evaluation of plant extracts for antifungal activity against Sclerotium rolfsii causing cocoyam cormel rot in storage, Res. J. Agr. Bio. 6 (2008) 784-787.

[12] O.O. Anyaele, A.A.S. Amusan, Toxicity of hexanolic extract of Dennettia tripetala (G. Baker) on larvae of Aedes aegypti (1), Afr. J. Biomed. Res. 6 (2003) 49-53.

[13] B. O. Ejechi, O. E. Nwafor, F. J. Okoko, Growth inhibition of Tomato-rot fungi by phenolic acids and essential oil extracts of pepper fruit, Food Res. Int. 32 (1999) 395-399.

[14] I.A. Oyemitan et al., Antinociceptive and anti-inflammatory effects of essential oil of Dennettia tripetala G. Baker (Annonaceae) in rodents, Afr. J. Trad. Compl. Alt. Med. 5 (2008) 355-362.

[15] A.O. Anaga, I.U. Asuzu, Glucose uptake-enhancing activity of the ethyl acetate extract of Dennettia tripetala in 3T3-L1 adipocytes, J. Compl. Integr. Med. (2011).

[16] A.O. Anaga, I.U. Asuzu, Antihyperglycaemic properties of the ethyl acetate extract of Dennettia tripetala in diabetic rats, J. Compl. Int. Med. 7(1) (2010).

[17] H.P. Misra, I. Fridovich, The role of superoxide anion in the autooxidation of epinephrine and simple assay for superoxide dismutase, J. Biol. Chem. 247 (1972) 3170-3175. 
[18] L. Goth, A simple method for determination of serum catalase activity and revision of reference range, Clin. Chim. Acta. 196 (1991) 143-151.

[19] J.A. Buege, S.D. Aust, Microsomal lipid peroxidation, Methods enzymol. 52 (1978) 302-310.

[20] A. Singh, T.K. Bhat, O.P. Sharma, Clinical biochemistry of hepatotoxicity, J. Clinic. Toxicol. S4 (2011) 1-19.

[21] A. Ihemeje et al., Biochemical evaluation of Pepperfruit (Dennettia tripetala) and its use as substitute for ginger in zobo drink production, Acad. Res. Int. 4 (2013) 513-521.

[22] M. Boll et al., Mechanism of carbon tetrachloride induced hepatotoxicity. Hepatocellular damage by reactive $\mathrm{CCl}_{4}$ metabolites, Z. Naturforsch. 56 (2001) 649-659.

[23] B. Fromentry, D. Pessayre, Inhibitional mitochondrial $\beta$-oxidation as a mechanism of hepatotoxicity, Pharmacol. Ther. 67 (1995) 101-154.

[24] H. Kato, Y. Nakazawa, The effect of $\mathrm{CCl}_{4}$ on the enzymatic hydrolysis of cellular triacylglycerol in adult rat hepatocytes in primary monolayer culture, Bio. Pharm. 36 (1987) 1807-1814.

[25] A.A.A. Khalaf et al., Comparative study on the protective effect of some antioxidants against $\mathrm{CCl}_{4}$ hepatotoxicity in rats, Egypt. J. Nat. Tox. 6 (2009) 59-82.

[26] J.S. Owen, Extra hepatic cell membrane lipid abnormalities and cellular dysfunction in liver disease, Drugs. 40 (1990) 73-83.

[27] C.E. Jahn et al., Lipoprotein abnormalities in primary biliary cirrhosis association with hepatic lipase inhibition as well as altered cholesterol esterification, Gastroenterology. 89 (1985) 1266-1278.

[28] U.Y. Sanzgiri et al., Uptake, distribution, and elimination of carbon tetrachloride in rat tissues following inhalation and ingestion exposures, Tox. Appl. Pharm. 143 (1997) 120-129.

[29] F. Jaramillo-Juarez et al., Acute renal failure induced by carbon tetrachloride in rats with hepatic cirrhosis, Annals of Hepatology. 7 (2008) 331-338. 